\title{
Study of Proportional Variation of Geopolymer Concrete which Self Compacting Concrete
}

\author{
Purwanto $^{1, *}$ and Himawan Indarto ${ }^{2}$ \\ ${ }^{I}$ Structural and Material Laboratory, Diponegoro University, Tembalang, Semarang, Indonesia \\ ${ }^{2}$ Civil Engineering Departement, Diponegoro University, Tembalang, Semarang, Indonesia. \\ * Corresponding author: purwatrend@gmail.com.
}

(Received: September 24 ${ }^{\text {th }}, 2019$; Accepted: October 22 $\left.2^{\text {nd }}, 2019\right)$

\begin{abstract}
The Portland cement production process which is one of the conventional concrete constituent materials always has an impact on producing carbon dioxide $\left(\mathrm{CO}_{2}\right)$ which will damage the environment. To maintain the continuity of development, while maintaining the environment, Portland cement substitution can be made with more environmentally friendly materials, namely fly ash. The substitution of fly ash material in concrete is known as geopolymer concrete. Fly ash is one of the industrial waste materials that can be used as geopolymer material. Fly ash is a mineral residue in fine grains produced from coal combustion which is mashed at a power plant power plant [15]. Many cement factories have used fly ash as a mixture in cement, namely Portland Pozzolan Cement or PPC. Because fly ash contains $\mathrm{SiO}_{2}, \mathrm{Al}_{2} \mathrm{O}_{3}$, $\mathrm{P}_{2} \mathrm{O}_{3}$, and $\mathrm{Fe}_{2} \mathrm{O}_{3}$ which are quite high, so fly ash is considered capable of replacing cement completely. This study aims to obtain geopolymer concrete which has the best workability so that it is easy to work on (Workable Geopolymer Concrete / Self Compacting Geopolymer Concrete) and obtain the basic characteristics of geopolymer concrete material in the form of good workability and compressive strength. In this study, geopolymer concrete is composed of coarse aggregate, fine aggregate, fly ash type $\mathrm{F}$, and activators in the form of $\mathrm{NaOH}$ and $\mathrm{Na}_{2} \mathrm{SiO}_{3} \mathrm{Be} 52$. In making geopolymer concrete, additional ingredients such as superplastizer are added to increase the workability of geopolymer concrete. From this geopolymer concrete research, the results of concrete compressive strength above fc' $25 \mathrm{MPa}$ and horizontal slump values reached 60 to 80 centimeters.
\end{abstract}

Keywords: geopolymer concrete; fly ash; workability; compression strength; horizontal slump

\section{Introduction}

With the increasing demand for concrete, cement production will also increase as a basis for making concrete. In the production process the cement emits $\mathrm{CO}_{2}$ gas which causes a greenhouse effect. Where in one ton of portland cement production will produce about one ton of carbon dioxide gas released into the atmosphere $[1,2,5]$. To reduce the greenhouse effect, a more environmentally friendly cement replacement material is needed. One of the technologies that can be used is geopolymer concrete, which is the synthesis of organic natural materials through the polymerization process where the main ingredients in making geopolymer materials are materials containing silicon and aluminum elements such as iron blast furnace slag, bottom ash, or fly ash, as industrial waste materials. Geopolymer concrete is concrete that is formed not from the results of a hydraulic reaction like conventional concrete, but is formed from chemical reactions [6,7]. Due to the use of fly ash in its manufacture, an activator is needed in the form of Sodium Hydroxide $(\mathrm{NaOH}) 8 \mathrm{M}$ to $14 \mathrm{M}$ and Sodium Silicate $\left(\mathrm{Na}_{2} \mathrm{SiO}_{3}\right) \mathrm{Be} 52$ with a ratio between 0.4 to 2.5 [3]. Geopolymer concrete can be said to be environmentally friendly because it can reduce $\mathrm{CO}_{2}$ gas up to $20 \%$ [2]. However, for the time being, the reference for planning geopolymer 
concrete mix design is unknown. This is because fly ash has a different chemical composition depending on the type of coal. Therefore, the researcher intends to provide a reference proportion of the comparison of geopolymer concrete materials to be used in determining the mix design of geopolymer concrete using fly ash type F from the Tanjung Jati B Jepara power plant.

Geopolymer concrete is made from a mixture of fly ash, coarse aggregates, fine aggregates, and alkaline activator solutions. If needed, an additional mixture (admixture) is provided in the form of a superplastizer to create a good level of concrete adhesiveness.

There have been many studies conducted to obtain high workability and compressive strength values, but until now there has not been found an optimal composition to achieve this. Therefore, geopolymer concrete research was carried out with the addition of conventional cement and extra water with a certain ratio to get the best workability and compressive strength.

\section{Literature Review on Geopolymer Concrete}

Self compacting geopolymer concrete (SCGC) is a geopolymer concrete made from fly ash material combined with alkaline activator and aggregate $[18,20]$. This Self compacting geopolymer concrete must have self-compacting concrete (SCC) workability criteria. To get the working ability of the SCC, extra water and superplasticizer are needed for the geopolymer concrete mixture. The addition of extra water in Geopolymer Concrete has a significant influence on the value of slump flow. Maximum compressive strength is obtained in the mixture without the addition of extra water / fly ash, the more water is added, the smaller the compressive strength produced. The optimal composition can be seen from the aspect of the inconvenience that meets the requirements of Self Compacting Geopolymer Concrete, namely the value of slump flow between $65-80 \mathrm{~cm}$ with the use of extra water / fly ash 0.3 with the result of a slump flow value of $67 \mathrm{~cm}$ and an average compressive strength of 16.28 MPa [12]. Based on research on the Effects of Polycarboxylate Ether (PCE) Levels on the Mechanical Properties of Fly Ash-Based Geopolymer Concrete, it can be concluded that the higher levels of PCE in geopolymer concrete mixtures cause a decrease in flow values. Adding a superplastizer to a geopolymer concrete can reduce the compressive strength of geopolymer concrete $[14,18,20]$. Geopolymer concrete with activator of $8 \mathrm{M} \mathrm{NaOH}$ solution has the greatest compressive strength compared to $6 \mathrm{M}$ and $10 \mathrm{M}$ $\mathrm{NaOH}$ solutions. The use of large enough $\mathrm{NaOH}$ affects the workability of geopolymer concrete so that the compressive strength of $10 \mathrm{M}$ concrete is smaller than that of $8 \mathrm{M}$ geopolymer concrete. Geopolymer concrete has a greater compressive strength than conventional concrete. At 28 days, $8 \mathrm{M}$ geopolymer concrete has a compressive strength of $75 \%$ greater than conventional concrete [13]. From the results of research conducted by Nico et,.al.[17] showed that geopolymer concrete (BG-1K) had the greatest compressive strength compared to cement concrete. Geopolymer concrete reaches a maximum compressive strength at 56 days, whereas at 90 days geopolymer concrete has a reduced compressive strength.

\section{Research Methodology}

The research work was conducted experimentally at the Construction and Material Laboratory, Civil Engineering Department, Diponegoro University and followed the steps as outlined in Figure. 1. The variable in this study was the cement ratio set at 5,10 and 15 percent with super plastizer ratio 2 and 5 percent. The specimens were 100 by $200 \mathrm{~mm}$ cylinders tested in compression at the ages of 90 days. 


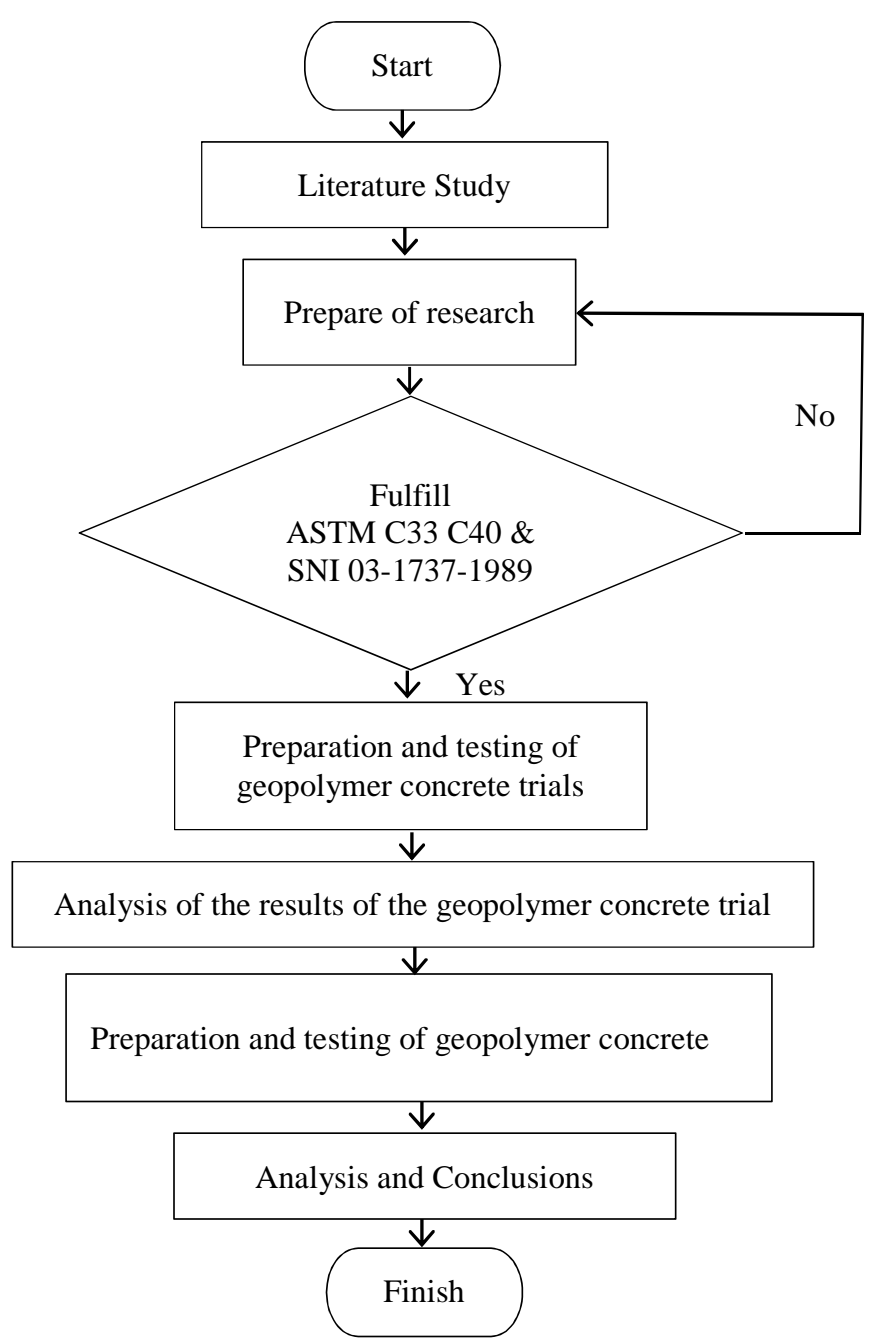

Fig. 1. Research outline

\subsection{Chemical composition testing on Fly Ash}

Chemical characteristics of the fly ash used can be influenced by the quality of the coal used, the combustion temperature at the power plant, and the time of taking, so that the fly ash that will be used can affect the behavior of the geopolymer concrete. Therefore it is necessary to analyze the composition of the fly ash using the Scanning Electron Microscopy - Energy Dispersive X-Ray (SEM-EDX) test method. The Scanning Electron Mocroscopy (SEM) test analyzes the texture, shape, and size of a nanometer-scale sample and Energy Dispersive X-Ray (EDX) analyzes the composition of the sample quantitatively and qualitatively.

In addition to the SEM-EDX test, the fly ash test also uses the X-Ray Fluorscence (XRF) test, which analyzes the chemical composition and concentration of the elements contained by the spectrometry method. The x-ray energy will be emitted then the intensity and energy of the x-ray will be measured qualitatively (element type) and quantitatively (elemental concentration).

\subsection{Mix design of geopolymer concrete}

Based on the analysis of the results of the trial of the geopolymer concrete specimens that have been carried out, obtained several results that meet the requirements, namely specimens WGCS- 
1,WGCS-2,SCGC-1. From these results, an analysis was carried out to create a mix design for geopolymer concrete specimens. Mix design of geopolymer concrete as follows :

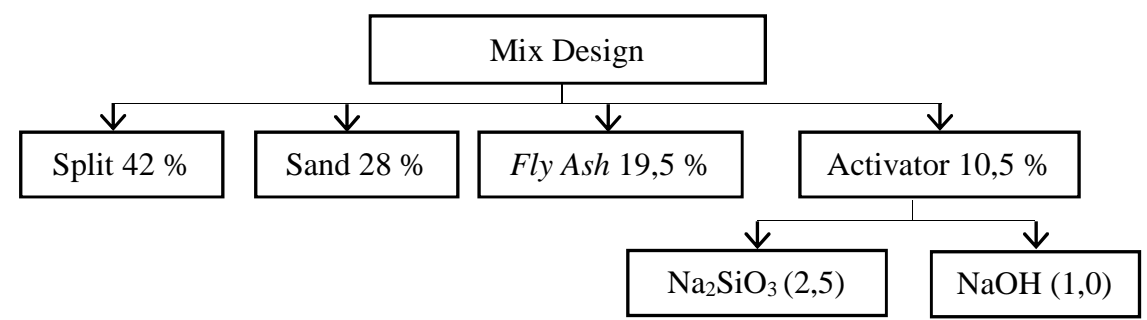

Fig. 2. Mix design of geopolymer

Table 2. Geopolymer concrete composition

\begin{tabular}{lccc}
\hline \multicolumn{1}{c}{ Materials } & WGCS-1 & WGCS-2 & SCGC-1 \\
\hline Aggregates : (FA + AA) & $70 \%: 30 \%$ & $70 \%: 30 \%$ & $70 \%: 30 \%$ \\
\hline Fine Aggregate : Coarse Agg & $40 \%: 60 \%$ & $40 \%: 60 \%$ & $40 \%: 60 \%$ \\
\hline Binder (FA) : AA (Alkaline Activator) & $65 \%: 35 \%$ & $65 \%: 35 \%$ & $65 \%: 35 \%$ \\
\hline $\mathrm{NaOH}(12 \mathrm{M}): \mathrm{Na}_{2} \mathrm{SiO}_{3}$ & $1: 2,5$ & $1: 2,5$ & $\begin{array}{c}1: 2,5(\mathrm{Na} 2 \mathrm{SiO} 3 \\
\mathrm{Be}-52)\end{array}$ \\
\hline Superplastizer-Viscocrete 1003 & $2 \% \mathrm{FA}$ & - & $2 \% \mathrm{FA}$ \\
\hline $\begin{array}{l}\text { Superplastizer-MasterGlenium } \\
\text { Sky8851 }\end{array}$ & - & $5 \% \mathrm{FA}$ & - \\
\hline
\end{tabular}

\subsection{Horizontal slump test}

To find out the good performance of geopolymer concrete with self compacting concrete criteria, a fresh concrete slump test can be performed. The slump test was carried out according to ASTM C143 (United States) procedure, IS: 1199 - 1959 (India) and EN 12350-2 (Europe). Test slump to determine the level of workability of a concrete mixture. The slump test uses the Abraham cone with horizontal slump measurements, as shown in Figure:

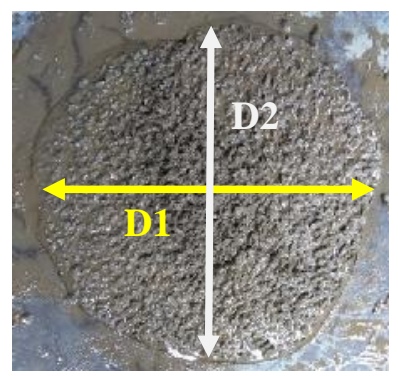

Fig. 3. Horizontal slump test

\subsection{Materials}

The fly ash used in this research work was originated from PT. Pembangkit Jawa Bali (PJB) PLTU Tanjung Jati B in Jepara. The fly ash has a chemical composition as listed in Table 3. 
Table 3. Fly ash PT.PJB PLTUTanjung Jati B - Jepara chemical composition

\begin{tabular}{|c|c|c|c|c|c|c|c|}
\hline \multirow{3}{*}{ Parameters } & \multirow{3}{*}{$\begin{array}{c}\text { Content } \\
(\%)\end{array}$} & \multicolumn{6}{|c|}{ Standardized to } \\
\hline & & \multicolumn{3}{|c|}{ ASTM C 618} & \multicolumn{3}{|c|}{ ACI Part 1 226-3R } \\
\hline & & $\mathbf{N}$ & $\mathbf{F}$ & $\mathbf{C}$ & $\mathbf{N}$ & $\mathbf{F}$ & $\mathbf{C}$ \\
\hline Silicon dioxide $\left(\mathrm{SiO}_{2}\right)$ & \multirow{3}{*}{76,87} & \multirow{3}{*}{70} & \multirow{3}{*}{70} & \multirow{3}{*}{50} & \multirow{3}{*}{-} & \multirow{3}{*}{70} & \multirow{3}{*}{50} \\
\hline Aluminum oxide $\left(\mathrm{Al}_{2} \mathrm{O}_{3}\right)$ & & & & & & & \\
\hline Iron oxide $\left(\mathrm{Fe}_{2} \mathrm{O}_{3}\right)$ & & & & & & & \\
\hline Calcium oxide $(\mathrm{CaO})$ & 11,48 & - & - & - & - & $<10$ & $>10$ \\
\hline Sulfur trioxide $\left(\mathrm{SO}_{3}\right)$ & 2,29 & 4 & 5 & 5 & - & 5 & 5 \\
\hline Moisture content & 0,33 & 3 & 3 & 3 & - & 3 & 3 \\
\hline Loss on ignition & 1,66 & 10 & 6 & 6 & - & 6 & 6 \\
\hline Sodium dioxide $\left(\mathrm{Na}_{2} \mathrm{O}\right)$ & 1,12 & - & 1,5 & 1,5 & - & 1,5 & 1,5 \\
\hline
\end{tabular}

Examining the chemical composition in accordance with ASTM C618-2010 [16], the fly ash from PJB PLTU Tanjung Jati B - Jepara is classified as class F type. The classification is based on the silicon dioxide $\left(\mathrm{SiO}_{2}\right)$, aluminum oxide $\left(\mathrm{Al}_{2} \mathrm{O}_{3}\right)$ and iron oxide $\left(\mathrm{Fe}_{2} \mathrm{O}_{3}\right)$ compounds that comprise a $76,87 \%$ of the total content, thus exceeding the minimum $70 \%$ mandated by the code for the classification of type $\mathrm{F}$ fly ash. The activator solution used in this study was sodium silicate $\left(\mathrm{Na}_{2} \mathrm{SiO}_{3}\right)$ and sodium hydroxide $(\mathrm{NaOH})$. The sodium silicate enhances the polymerization reaction, whiles the sodium hydroxide reacts with the aluminum $(\mathrm{Al})$ and silica $(\mathrm{Si})$ of the fly ash, resulting in a strong bond polymer [10].

\subsection{Concrete mix proportions}

The mix proportions of basic material for the geopolymer concrete are shown in Table 4.

Table 4. Mix proportions for geopolymer concrete

\begin{tabular}{cc}
\hline Remarks & $\begin{array}{c}\text { Volumetric } \\
\text { Composition }\end{array}$ \\
\hline Aggregate to binder and activator & $70 \%$ to $30 \%$ \\
\hline Coarse to fine aggregates & $60 \%$ to $40 \%$ \\
\hline Binder $\left(\right.$ fly ash) to activator $\left(\mathrm{Na}_{2} \mathrm{SiO}_{3}\right.$ and $\left.\mathrm{NaOH}\right)$ & $65 \%$ to $35 \%$ \\
\hline $\mathrm{Na}_{2} \mathrm{SiO}_{3}$ to $\mathrm{NaOH}$ ( 8 to 14 molars) & 2,5 to 1 \\
\hline
\end{tabular}

The determination of proportion percentage to the total is as following

Coarse aggregate proportion $\quad=70 \% \times 60 \%=42,0 \%$

Fine aggregate proportion $\quad=70 \% \times 40 \%=28,0 \%$

Binder (fly ash) proportion $\quad=30 \% \times 65 \%=19,5 \%$

Activator proportion $\quad=30 \% \times 35 \%=10,5 \%$

The conventional concrete has an identic material mix proportions. The binder (fly ash) for the geopolymer concrete was here replaced by cement, and the activator by water. The mix proportions of basic material for the controlling concrete are shown in Table 5.

Table 5. Mix proportions for conventional concrete

\begin{tabular}{cc}
\hline Remarks & Volumetric Composition \\
\hline Aggregate to cement and water & $70 \%$ to $30 \%$ \\
\hline Coarse to fine aggregates & $60 \%$ to $40 \%$ \\
\hline Cement to water & $65 \%$ to $35 \%$ \\
\hline
\end{tabular}




\section{Result and Analyses}

\subsection{Characteristics of Fly Ash}

Fly ash testing is done using SEM EDX and XRF methods. The results of testing the chemical composition of fly ash material from PLTU Tanjung - Jati B Jepara can be seen in Figure 4 and Table 6

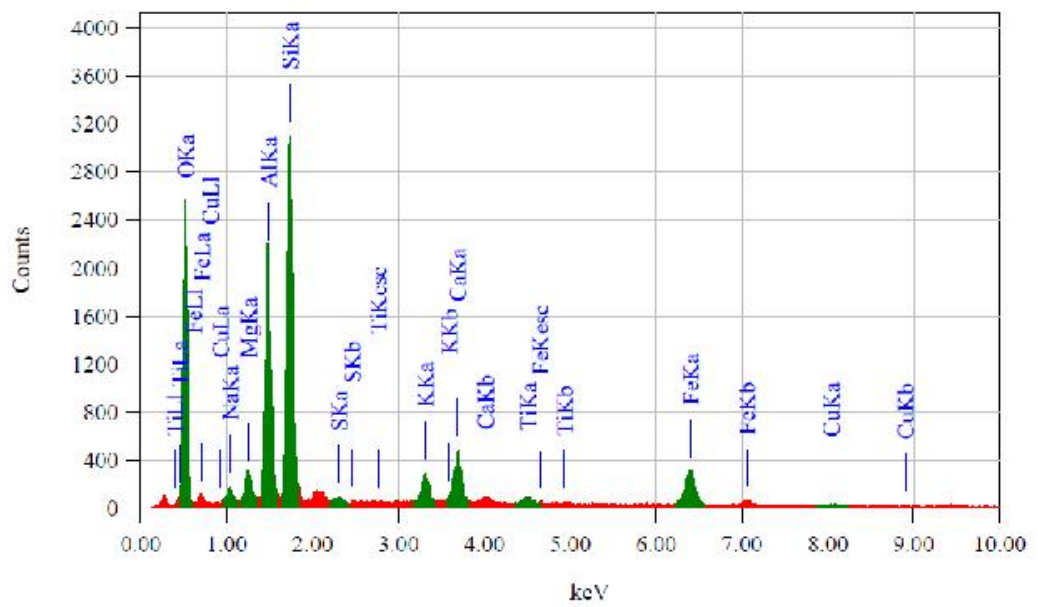

Fig. 4. SEM Analysis of EDX Fly Ash PLTU Tanjung - Jati B Jepara

Table 6. Chemical Composition of Ash Ash PLTU Tanjung - Jati B Jepara

\begin{tabular}{|c|c|c|}
\hline Composition & Percentage (\%) & Remarks \\
\hline $\mathrm{Na}_{2} \mathrm{O}$ & 1,59 & \multirow{10}{*}{$\begin{array}{l}\text { Fly ash PLTU Tanjung - Jati B } \\
\text { Jepara is type } \mathrm{F} \text { fly ash because it } \\
\text { contains } \mathrm{CaO}<10 \% \text { and total } \\
\text { levels of } \mathrm{SiO}_{2}, \mathrm{Al}_{2} \mathrm{O}_{3} \text {, and } \mathrm{FeO}> \\
70 \% \text {. }\end{array}$} \\
\hline $\mathrm{MgO}$ & 2,86 & \\
\hline $\mathrm{Al}_{2} \mathrm{O}_{3}$ & 24,95 & \\
\hline $\mathrm{SiO}_{2}$ & 46,52 & \\
\hline $\mathrm{SO}_{3}$ & 1,13 & \\
\hline $\mathrm{K}_{2} \mathrm{O}$ & 2,77 & \\
\hline $\mathrm{CaO}$ & 5,89 & \\
\hline $\mathrm{TiO}_{2}$ & 1,36 & \\
\hline $\mathrm{FeO}$ & 11,81 & \\
\hline $\mathrm{CuO}$ & 1,12 & \\
\hline
\end{tabular}

\subsection{Trial of geopolymer concrete samples}

Before conducting geopolymer concrete research, a geopolymer concrete trial is first carried out. It aims to get a mix design with the results of the slump value and compressive strength of concrete in accordance with predetermined limits. Geopolymer concrete specimen will be tested for slump value and compressive strength at 90 days. The test results of geopolymer concrete specimens can be seen in Table $7 \mathrm{a}$ and Table $7 \mathrm{~b}$. 
Table 7a. Trial Test Results for Geopolymer Concrete samples

\begin{tabular}{ccccccc}
\hline Code & $\begin{array}{c}\text { Age } \\
(\mathbf{d a y})\end{array}$ & $\begin{array}{c}\text { weight } \\
(\mathbf{k g})\end{array}$ & $\begin{array}{c}\text { Volume } \\
\left.\mathbf{( m}^{\mathbf{3}}\right)\end{array}$ & $\begin{array}{c}\text { Specific } \\
\text { gravity } \\
\left(\mathbf{k g} / \mathbf{m}^{\mathbf{3}}\right)\end{array}$ & $\begin{array}{c}\text { Compressive } \\
\text { Strength } \\
(\mathbf{M P a})\end{array}$ & $\begin{array}{c}\text { Slump } \\
(\mathbf{c m})\end{array}$ \\
\hline WGC1 & 90 & 3,730 & 0,001571 & 2374,59 & 47,43 & 0 \\
\hline WGC2 & 90 & 3,700 & 0,001571 & 2355,49 & 35,03 & 0 \\
\hline WGC3 & 90 & 3,710 & 0,001571 & 2361,86 & 33,86 & 0 \\
\hline WGC4 & 90 & 3,750 & 0,001571 & 2387,32 & 29,33 & 0 \\
\hline WGC5 & 90 & 3,800 & 0,001571 & 2419,16 & - & 0 \\
\hline WGC6 & 90 & 3,760 & 0,001571 & 2393,69 & 46,30 & 0 \\
\hline WGC7 & 90 & 3,680 & 0,001571 & 2342,76 & 34,42 & 0 \\
\hline WGC8 & 90 & 3,670 & 0,001571 & 2336,39 & 30,02 & 0 \\
\hline WGC9 & 90 & 3,630 & 0,001571 & 2310,93 & 26,59 & 0 \\
\hline WGC10 & 90 & 3,720 & 0,001571 & 2368,23 & 34,67 & 35,0 \\
\hline WGC11 & 90 & 3,690 & 0,001571 & 2349,13 & 31,35 & 30,2 \\
\hline WGC12 & 90 & 3,700 & 0,001571 & 2355,49 & $\mathbf{3 0 , 5 0}$ & $\mathbf{2 8 , 9}$ \\
\hline WGC13 & 90 & 3,810 & 0,001571 & 2425,52 & $\mathbf{2 6 , 3 9}$ & $\mathbf{2 8 , 3}$ \\
\hline WGC14 & 90 & 3,700 & 0,001571 & 2355,49 & $\mathbf{3 1 , 8 5}$ & $\mathbf{2 8 , 0}$ \\
\hline WGC15 & 90 & 3,820 & 0,001571 & 2431,89 & 29,35 & 34,0 \\
\hline WGC16 & 90 & 3,810 & 0,001571 & 2425,52 & $\mathbf{2 3 , 5 7}$ & $\mathbf{3 3 , 5}$ \\
\hline WGC17 & 90 & 3,760 & 0,001571 & 2393,69 & $\mathbf{3 2 , 4 5}$ & $\mathbf{3 1 , 0}$ \\
\hline WGC18 & 90 & 3,780 & 0,001571 & 2406,42 & $\mathbf{3 2 , 1 2}$ & $\mathbf{3 0 , 0}$ \\
\hline WGC19 & 90 & 3,760 & 0,001571 & 2393,69 & 27,02 & 27,0 \\
\hline WGC20 & 90 & 3,720 & 0,001571 & 2368,23 & 23,91 & 28,0 \\
\hline WGC21 & 90 & 3,860 & 0,001571 & 2457,35 & 34,04 & 0 \\
\hline WGC22 & 90 & 3,750 & 0,001571 & 2387,32 & 51,96 & 0 \\
\hline WGC23 & 90 & 3,560 & 0,001571 & 2266,37 & 24,13 & 0 \\
\hline WGC24 & 90 & 3,680 & 0,001571 & 2342,76 & 38,35 & 0 \\
\hline WGC25 & 90 & 3,690 & 0,001571 & 2349,13 & 26,62 & 0 \\
\hline
\end{tabular}

Source: Analysis Results (Research, 2019)

Table 7b. Trial Test Results for Geopolymer Concrete samples

\begin{tabular}{|c|c|c|c|c|c|c|}
\hline Code & $\begin{array}{l}\text { Age } \\
\text { (day) }\end{array}$ & $\begin{array}{l}\text { weight } \\
\text { (kg) }\end{array}$ & $\begin{array}{c}\text { Volume } \\
\left(\mathbf{m}^{3}\right)\end{array}$ & $\begin{array}{c}\text { Specific } \\
\text { gravity } \\
\left(\mathrm{kg} / \mathrm{m}^{3}\right)\end{array}$ & $\begin{array}{c}\text { Compressive } \\
\text { Strength } \\
\text { (MPa) }\end{array}$ & $\begin{array}{c}\text { Slump } \\
\text { (cm) }\end{array}$ \\
\hline WGC26 & 90 & 3,810 & 0,001571 & 2425,52 & 28,49 & 0 \\
\hline WGC27 & 90 & 3,640 & 0,001571 & 2317,30 & 25,71 & 0 \\
\hline WGC28 & 90 & 3,720 & 0,001571 & 2368,23 & 15,79 & 0 \\
\hline WGC29 & 90 & 3,770 & 0,001571 & 2400,06 & 27,90 & 0 \\
\hline WGC30 & 90 & 3,830 & 0,001571 & 2438,25 & 40,92 & 0 \\
\hline WGC31 & 90 & 3,720 & 0,001571 & 2368,23 & 44,73 & 0 \\
\hline WGC32 & 90 & 3,550 & 0,001571 & 2260,00 & 17,87 & 0 \\
\hline WGC33 & 90 & 3,640 & 0,001571 & 2317,30 & 25,54 & 0 \\
\hline WGC34 & 90 & 3,810 & 0,001571 & 2425,52 & 21,79 & 38,0 \\
\hline WGC35 & 90 & 3,620 & 0,001571 & 2304,56 & 8,81 & 46,0 \\
\hline WGC36 & 90 & - & 0,001571 & - & - & 0 \\
\hline WGC37 & 90 & 3,710 & 0,001571 & 2361,86 & 12,18 & 45,0 \\
\hline WGC38 & 90 & 3,700 & 0,001571 & 2355,49 & 15,73 & 41,0 \\
\hline
\end{tabular}

Source: Analysis Results (Research, 2019) 
From the results of the geopolymer concrete trial test, various results were obtained, so that the results were taken in accordance with predetermined limits, which have a compressive strength greater than $25 \mathrm{MPa}$ and a minimum slump value of $28 \mathrm{~cm}$. The results are then analyzed to get a mix design that has optimum compressive strength and slump value.

Table 8. WGCS-1 Geopolymer Concrete test sample

\begin{tabular}{ccc}
\hline Code & $\begin{array}{c}\text { Compressive } \\
\text { Strength } \\
\text { (MPa) }\end{array}$ & $\begin{array}{c}\text { Slump } \\
(\mathbf{c m})\end{array}$ \\
\hline WGC12 & 30,50 & 28,9 \\
\hline WGC13 & 26,39 & 28,3 \\
\hline WGC14 & 31,85 & 28,0 \\
\hline
\end{tabular}

WGCS-1

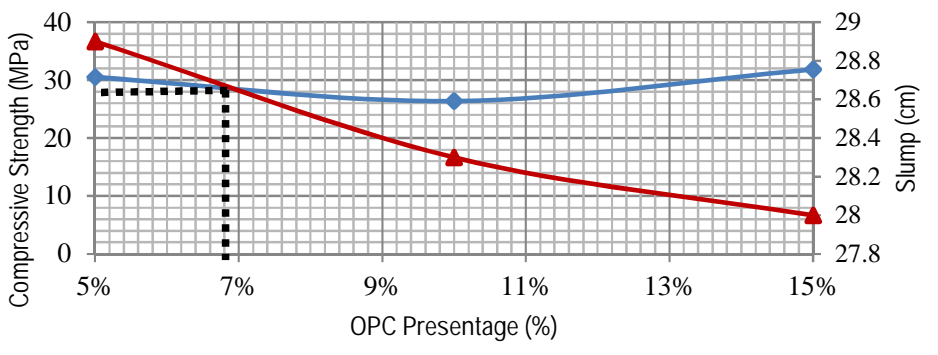

Fig. 5. WGCS-1 Geopolymer Concrete test sample

Table 9. WGCS-2 Geopolymer Concrete test sample

\begin{tabular}{ccc}
\hline Code & $\begin{array}{c}\text { Compressive } \\
\text { Strength } \\
\text { (MPa) }\end{array}$ & $\begin{array}{c}\text { Slump } \\
\text { (cm) }\end{array}$ \\
\hline WGC16 & 23,57 & 33,5 \\
\hline WGC17 & 32,45 & 31,0 \\
\hline WGC18 & 32,12 & 30,0 \\
\hline
\end{tabular}

\section{WGCS-2}

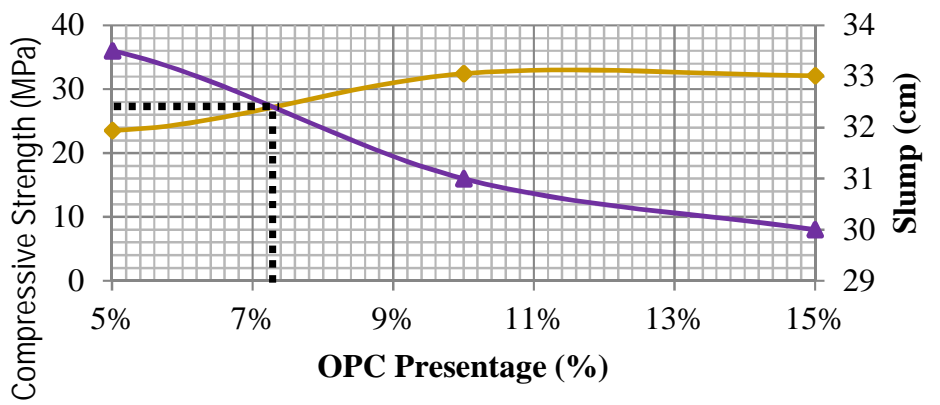

Fig. 6. WGCS-2 Geopolymer Concrete test sample 


\subsection{Mix design of geopolymer concrete}

Based on the results of the analysis of the geopolymer concrete trial, a mix design of the geopolymer concrete specimen is obtained as in Table 10

Table 10. Mix design of geopolymer concrete

\begin{tabular}{|c|c|c|c|c|c|c|c|}
\hline \multirow[b]{2}{*}{ Code } & \multirow{2}{*}{$\begin{array}{c}\text { Sand : } \\
\text { Split } \\
(\%)\end{array}$} & \multirow{2}{*}{$\begin{array}{c}\text { Fly Ash : } \\
\text { Alkaline } \\
\text { Activator } \\
(\%)\end{array}$} & \multirow{2}{*}{$\begin{array}{c}\mathrm{NaOH}: \\
\mathrm{Na}_{2} \mathrm{SiO}_{3} \\
(\%)\end{array}$} & \multirow{2}{*}{$\begin{array}{c}\text { OPC } \\
(\%)\end{array}$} & \multirow{2}{*}{$\begin{array}{c}\text { Extra } \\
\text { Water } \\
(\%)\end{array}$} & \multicolumn{2}{|c|}{ Superplastizer } \\
\hline & & & & & & type & $\%$ \\
\hline WGCS-1 & $40: 60$ & $65: 35$ & $1: 2,5$ & 5,63 & 11,70 & $\begin{array}{c}\text { Viscocrete } \\
1003 \\
\end{array}$ & 2 \\
\hline WGCS-2 & $40: 60$ & $65: 35$ & $1: 2,5$ & 6,60 & 11,98 & $\begin{array}{c}\text { Masterglenium } \\
\text { Sky } 8851\end{array}$ & 5 \\
\hline SCGC-1 & $40: 60$ & $65: 35$ & $\begin{array}{c}1: 2,5 \\
\mathrm{Na}_{2} \mathrm{SiO}_{3} \\
\mathrm{Be52}\end{array}$ & 5,63 & 11,70 & $\begin{array}{c}\text { Viscocrete } \\
1003\end{array}$ & 2 \\
\hline
\end{tabular}

Source: Analysis Results (Research, 2019)

The specimens used for testing compressive strength and slump are cylindrical concrete with a size of $10 \times 20 \mathrm{~cm}$. The making of test specimens aims to obtain an optimum mix design in accordance with the results of the analysis of the geopolymer concrete specimen trials. The results of compressive strength and slump testing of geopolymer concrete specimens can be seen in Table 11

Table 11. Test results for geopolymer concrete samples

\begin{tabular}{ccccccc}
\hline Code & $\begin{array}{c}\text { Uge } \\
(\mathbf{d a y})\end{array}$ & $\begin{array}{c}\text { Weight } \\
(\mathbf{k g})\end{array}$ & $\begin{array}{c}\text { Volume } \\
(\mathbf{m 3})\end{array}$ & $\begin{array}{c}\text { Specific } \\
\text { Gravity } \\
(\mathbf{k g} / \mathbf{m})\end{array}$ & $\begin{array}{c}\text { Compressive } \\
\text { Strength } \\
(\mathbf{M P a})\end{array}$ & $\begin{array}{c}\text { Slump } \\
(\mathbf{c m})\end{array}$ \\
\hline WGCS-1 & 90 & 3,700 & 0,001571 & 2355,19 & 31,20 & 30,0 \\
\hline WGCS-2 & 90 & 3,690 & 0,001571 & 2349,13 & 28,31 & 32,5 \\
\hline SCGC-1 & 90 & 3,720 & 0,001571 & 2356,20 & $\mathbf{3 2 , 5 0}$ & $\mathbf{6 5 , 0}$ \\
\hline
\end{tabular}

Source: Analysis Results (Research, 2019)

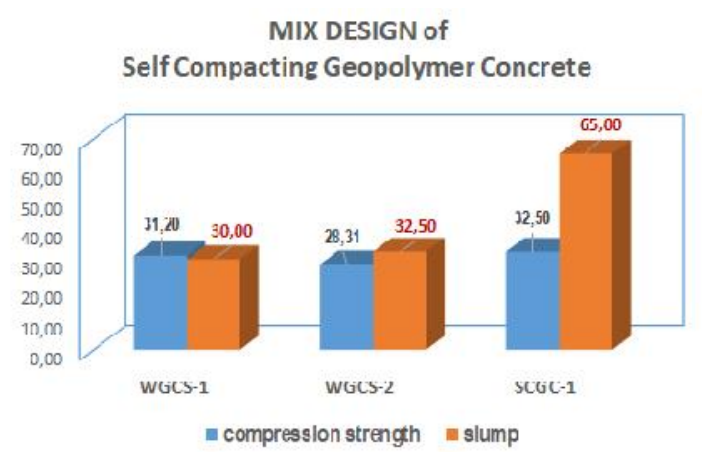

Fig. 7. Test Results for Geopolymer Concrete samples 
Based on the test results of geopolymer concrete specimens, it was found that the Mix Design WGCS-1 and WGCS-2 had met the specified limits, namely compressive strength>25 $\mathrm{MPa}$ and a slump value $\geq 30 \mathrm{~cm}$. As for SCGC-1 (Self Compacting Geopolymer Concrete) by changing the type of $\mathrm{Na}_{2} \mathrm{SiO}_{3}$ to $\mathrm{Na}_{2} \mathrm{SiO}_{3} \mathrm{Be} 52$ which is more liquid, $32.50 \mathrm{MPa}$ compressive strength and horizontal slump value of $65 \mathrm{~cm}$ are obtained.

\section{Conclusion}

1. To achieve workable geopolymer concrete, extra water is needed to increase the slump value.

2. The type and dosage of superplastizer that is used greatly affects the elasticity and quality of the concrete. Each type of SP has a different dosage to get the optimum slump value and compressive strength. The more doses of SP used, will reduce the quality of concrete and make concrete bleed. If the SP dose is used a little / less, then the expected damage can not be obtained.

3. Comparison of fly ash with alkaline activator affects the slump value and compressive strength of geopolymer concrete.

4. To achieve a geopolymer concrete that can solidify by itself, the type of alkaline activator used $\left(\mathrm{Na}_{2} \mathrm{SiO}_{3}\right)$ of the type $\mathrm{Na}_{2} \mathrm{SiO}_{3} \mathrm{Be}-52$.

5. The result of SCGC-1 geopolymer concrete design mix reaches a minimum compressive strength of $25 \mathrm{MPa}$ and a horizontal slump value of $65 \mathrm{~cm}$.

\section{References}

[1] Hardjito, D., Properties of Geopolymer Cements. First International Conference on Alkaline Cements and Concrete. 1994. Ukraine. (131-149)

[2] Hardjito, D., Enviromentally Driven Geopolymer Cement Applications. Geopolymer Conference. 2002. Australia.

[3] Hardjito, D., Wallah, S.E., Sumajouw, D.M.J., Rangan, B.V., Fly Ash-Based Geopolymer Concrete. Australian Journal of Structural Engineering. 2005. Australia. Vol.6 No. 1

[4] Hardjito, Djwantoro. Rangan. 2005. Development and Properties of Low-Calcium Fly AshBased Geopolymer Concrete. Research Report GC 1. Curtin University of Technology

[5] McCaffrey, R., Climate Change and the Cement industry. Global Cement and Lime Magazine (Enviromental Special Issue). 2002. (15-19)

[6] Davidovits, J., High-Alkali Cements for 21st Century Concretes. ACI Concrete International. 1994. Vol 144 (383-397).

[7] Davidovits, J., 30 Years of Successes and Failures in Geopolymer Applications. Market Trends and Potential Breakthroughs. Geopolymer Conference. 2002. Australia

[8] Rangan, B.V, Hardjito, D, Wallah, S.E, Sumajouw, D.M.J., Properties and Applications of Fly Ash-Based Concrete. Materials Forum. 2006. Australia. Vol.30 (170-175).

[9] ASTM C618., Standard Specification for Coal Fly Ash and Raw or Calcined Natural Pozzolan for Use in Concrete. ASTM International. 2017. West Conshohocken.

[10] Marthin, D.J, Sumajouw D.M.J, Reky, S.W., Kuat Tekan Beton Geopolymer Berbahan Dasar Abu Terbang (Fly Ash). Jurnal Sipil Statik. 2014. Manado. Vol. 2 No.6 (277-282).

[11] Mulyana, F., Yolanda, T., Studi Properties Beton Geopolimer Sebagai Subtitusi Beton Konvensional. Skripsi Universitas Diponegoro. 2017. Semarang

[12] Gumalang, S., dkk. 2016. Pengaruh Kadar Air dan Superplastizer Pada Kekuatan dan Kelecakan Beton Geopolimer Memadat Sendiri Berbasis Abu Terbang. Universitas Sam Ratulangi. Manado.

[13] Syaputra, D. A., Nugroho, F. R. 2017. Studi Experimental Pengaruh Perbedaan Molaritas Aktivator pada Perilaku Beton Geopolimer Berbahan Dasar Fly Ash. Universitas Diponegoro. Semarang.

[14] Putra, E.P., dkk. 2016. Efek Kadar Polycarboxylate Ether (PCE) terhadap Sifat Mekanik Beton Geopolimer Berbasis Fly Ash.Institut Teknologi Nasional. Bandung. 
[15] Sukamto, B. 2013.Pemanfaatan Limbah Fly Ash Batubara.Universitas Lampung. Lampung. [16] ASTM C 618. 2010. Standard Specification for Coal Fly Ash and Raw or Calcined Natural Pozzolan for Use. ASTM International. US.

[17] Nico, S., Putri, T. 2019. Studi Eksperimental Variasi Proporsi Material Penyusun Beton Geopolimer Menggunakan Fly Ash Tipe F Dari Pltu Tanjung Jati Jepara. Universitas Diponegoro. Semarang.

[18] Wigestika, P., dkk. 2015. Pengaruh Penambahan Superplastizer Pada Kinerja Beton Geopolimer. Institut Teknologi Sepuluh Nopember. Surabaya.

[19] ACI Committee 232. 2002. Use of Fly Ash in Concrete. American Concrete Institute. Detroit.

[20] Aer, Anggie Adityo. Marthin Sumajouw, Ronny Pandaleke. 2014. Pengaruh Variasi Kadar Superplasticizer Terhadap Nilai Slump Beton Geopolymer. Jurnal Sipil Statik 2 (6) : 283 191

[21] ASTM C143. 2007. Slump of Hydraulic Cement Concrete. ASTM International. US.

[22] Himawan, A. Darma D S. 2000. Penelitian Mengenai Awal Self Compacting Concrete. Jurusan Teknik Sipil Universitas Kristen Petra Surabaya.

[23] Purwanto. Han Ay Lie, Nuroji, Januarti Jaya Ekaputri. 2018. The Influence of Molarity Variations to The Mechanical Behavior of Geopolymer Concrete. MATEC Web of Conference 195, 01010.

[24] Rahmadia, Annisa. Januarti Jaya Ekaputri. 2017. Mechanical Properties of Geopolymer Concrete Exposed to Combustion. MATEC Web of Conference 138, 01022.

[25] Risdanareni, Puput. Poppy Puspitasari, Januarti Jaya Ekaputri. 2017. Chemical and Physical Characterization of Fly Ash as Geopolymer Material. MATEC Web of Conference 97, 01031.

[26] Subekti, Srie. Triwulan, Muji Irawan. 2008. Beton Geopolimer Berbahan Dasar Fly Ash Dengan Molaritas 8 Mol 1,5 dan 12 Mol 1,5 Tahan Terhadap Agresifitas Air Laut Selat Madura. 